\title{
METAL COMPLEXES WITH DIHYDRAZONE OF MALONIC ACID DIHYDRAZINE
}

\author{
R.H. İsmayilov ${ }^{1}$, P.A.Fatullayeva ${ }^{2}$ \\ 1"OilGasScientificResearchProjekt" İnstitute, Socar, Baku, Azerbaijan \\ ${ }^{2}$ Institute of Catalysis and Inorganic Chemistry, National Academy of Sciences of Azerbaijan, Baku, Azerbaijan
}

\author{
Metal complexes with dihydrazone of malonic acid dihydrazine \\ R.H. Ismayilov ${ }^{1}$, P.A.Fatullayeva ${ }^{2}$ \\ 1"OilGasScientificResearchProjekt" İnstitute, Socar, Baku, Azerbaijan \\ ${ }^{2}$ Institute of Catalysis and Inorganic Chemistry, NAS of Azerbaijan, Baku, Azerbaijan
}

\begin{abstract}
This research includes synthesis and characterization of transition metal complexes of $\mathrm{Cu}$ (II), Co (II) and Ni (II) with hydrazone Schiff base ligand. Schiff base lagand was synthesized by reaction of malonic ester dihydrazide and 5-bromo salicylaldehyde. The structure of obtained complexes was studied by IR and electron spectroscopy
\end{abstract}

e-mail: inazim17@yahoo.com

https://doi.org/10.53404/Sci.Petro.20210100008

\section{KEYWORDS}

hydrazone Schiff base ligand; copper complex; nickel complex; cobalt complex; IR and UV-Vis spectroscopy.

\section{Introduction}

The synthesis of complex compounds of hydrazone and its derivatives with its transition metals, the study of their structure and properties is one of the most intensively studied areas of chemistry of coordination compounds in the last 20 years [1-5]. Hydrazones exhibit several coordination sites, and they can easily coordinate with transitional metals to form transition metal complexes and show good biological properties. They are prepared by the reaction of hydrazide ( $\mathrm{R}-\mathrm{NH}-\mathrm{NH} 2)$ and a carbonyl $(\mathrm{C}=\mathrm{O})$ compound (-aldo and -keto). Hydrazones of hydrazides, mono- and dicarboxylic acids open up a wide range of possibilities for the production of polydentate ligands. For example, dihydrazones of hydrazides of dibasic carbonic acids are polydentate ligands, forming mono-, di- and trinuclear complexes with transition metals.

Coordination compounds containing polydentate ligands are called chelates (from Greek chole, "claw"), and their formation is termed chelation. They can act as multidentate ligands when interacted with transition metals and show many applications in industry, agriculture, and applied in various fields of medicine [6, 7]. They have physiological and biological activities such as, in biological activities enable the hydrazone compounds and their complexes are suitable to be used as herbicides, insecticides, nematicides, rodenticides, and plant growth regulators. Acylhydrazones and their transition metal complexes are included in the drugs used against tuberculosis and oncological diseases. They also show antimicrobial properties $[1,2]$. The structure and properties of coordination compounds are determined by the structure of the organic ligand. Many different types of organic ligands are now known to be able to bind metal ions strongly. In this case, the structure of complex compounds depends on the electronic properties of the heteroatoms that make up the ligand, the number of coordinating atoms (dentate), their relative position, and the elasticity of the ligands.

\section{Experimental}

2.1. Materials and measurements

All reagents and solvents were obtained from commercial sources and were used without further purification unless otherwise noted.

Electron absorption spectra were recorded on a UV-VIS Evolution 60S spectrophotometer. IR spectra were performed from KBr pellets with a Nicolet IS10 spectrophotometer from Thermo Scientific (USA) in the range of $400-4000 \mathrm{~cm}^{-1}$.

2.2. Preparation of compounds

2.2.1. Malonic acid dihydrazide

The mixture of $3.2 \mathrm{~g}(0.02 \mathrm{~mol})$ of malonic acid diethyl ester and $4 \mathrm{~g} 50 \%$ hydrazine was refluxed for 5 hours. After cooling, the crude mixture was filtered and kept at room temperature for 1 day. The next day precipitated white crystals. Crystals were 
washed with distilled water several times and dried. M.p. $150{ }^{\circ} \mathrm{C}$.<smiles>CCOC(=O)CC(=O)OCC</smiles>

2.2.2. Synthesis of hydrazone from diethyl malonate dihydrazide with 5-bromo salicylic aldehyde (1)

The solutions $1.32 \mathrm{q}\left(10^{-2} \mathrm{~mol}\right)$ malonic ester dihydrazide dissolved in $20 \mathrm{ml}$ of methanol and $3.82 \mathrm{~g}$ $\left(2 \cdot 10^{-2} \mathrm{~mol}\right)$ 5-bromo salicylic aldehyde dissolved in $30 \mathrm{ml}$ of ethanol were mixed and stirred on a magnetic stirrer at a temperature of $30-40{ }^{\circ} \mathrm{C}$ during 2 hours. Then the solution was filtered to remove insoluble impurities. After 20 minutes, light yellow crystals appeared, which were separated and dried in the air. IR $(\mathrm{KBr}) v / \mathrm{cm}^{-1}=3279 \mathrm{~m}, 3179 \mathrm{~m}, 1754 \mathrm{~s}$, $1735 \mathrm{~s}, 1698 \mathrm{~s}, 1608 \mathrm{~s}, 1505 \mathrm{~s}, 1463 \mathrm{~s}, 1377 \mathrm{~m}, 1343 \mathrm{~m}$, $1260 \mathrm{w}, 1173 \mathrm{w}, 822 \mathrm{w}, 722 \mathrm{w}, 636 \mathrm{w}, 488 \mathrm{w}$.

2.2.3. Synthesis of $\mathrm{Cu}(\mathrm{II})$ complex (2)

Schiff base ligand (hydrazone) and $\mathrm{Cu}\left(\mathrm{NO}_{3}\right)_{2} \times 3 \mathrm{H}_{2} \mathrm{O}$ in a 1:1 ratio were used for the synthesis. A mixture of $0.72 \mathrm{~g}$ (0.01 mole) of ligand, $0.24 \mathrm{~g}$ (0.01 mole) copper nitrate, and $0.2 \mathrm{~g}$ of $\mathrm{NaOH}$ in methanol: water solution (ratio 5:1, $20 \mathrm{~mL}$ ) was stirred about 15-20 minutes on a magnetic stirrer. Immediately the color changed to dark green. The substance precipitates in the solution as a green powder. The solid compound is filtered and dried. The melting point is determined Tm.p. $>250^{\circ} \mathrm{C}$. IR (KBr) $v / \mathrm{cm}^{-1}=3589 \mathrm{~m}, 3205$ wide, $1662 \mathrm{~s}, 1617 \mathrm{~m}, 1524 \mathrm{~m}, 1467 \mathrm{~m}, 1373 \mathrm{~s}, 1286 \mathrm{~s}, 1181 \mathrm{~m}$, $834 w, 703 w$.

\subsubsection{Synthesis of $\mathrm{Ni}(\mathrm{II})$ complex (3)}

Schiff base ligand (hydrazone) and $\mathrm{Ni}\left(\mathrm{NO}_{3}\right)_{2} \times 6 \mathrm{H}_{2} \mathrm{O}$ in a $1: 1$ ratio were used for the synthesis. $0.72 \mathrm{~g}(0.01 \mathrm{~mol})$ of ligand was dissolved in $20 \mathrm{ml}$ ethanol and $0.29 \mathrm{~g}(0.01 \mathrm{~mol})$ $\mathrm{Ni}\left(\mathrm{NO}_{3}\right)_{2} \times 6 \mathrm{H}_{2} \mathrm{O}$ was dissolved in $30 \mathrm{ml}$ methanol. Then these solutions were mixed and stirred for about 5 minutes on the magnetic stirrer. The substance precipitates in the solution as a greenishyellow powder. The solution was filtered and dried. M.p. $>250^{\circ} \mathrm{C}$. IR (KBr) $v / \mathrm{cm}^{-1}=3465 \mathrm{~m}, 3047$ wide, $1694 \mathrm{w}, 1606 \mathrm{~m}, 1520 \mathrm{~m}, 1457 \mathrm{~m}, 1359 \mathrm{~s}, 1289 \mathrm{~m}, 1174 \mathrm{~s}$, $1085 \mathrm{w}, 847 \mathrm{~m}, 825 \mathrm{w}, 652 \mathrm{w}$.

2.2.5. Synthesis of $\mathrm{Co}(\mathrm{II})$ complex (4)

The Co (II) complex was obtained in a similar way as a $\mathrm{Ni}(\mathrm{II})$ complex. The substance precipitates in the solution as a dark red powder. The solution was filtered and dried. M.p. $>250{ }^{\circ} \mathrm{C}$.

\section{Results and discussion}

Malonic acid dihydrazide has a high elasticity due to its ability to rotate around the methylene group compared to other similar dibasic acids (oxalate, phthalic, etc.). The carbonyl group combined with the hydrazone group can be converted to keto and enol forms, and the hydrogen atom can be deprotonated during coordination. Therefore, dihydrazone from bis-salicylic acid of malonic acid dihydrazide acts as a potential mono-, bi-, tetraanion ligand during coordination. $\mathrm{Cu}$ (II), Co (II), and Ni (II) complexes were synthesized with 5-Br-salicyl hydrazone of malonic acid.<smiles>O=C(CC(=O)N/N=C\c1cc(Br)ccc1O)N/N=C\c1cc(Br)ccc1O</smiles>

\section{IR Spectra of Ligand and Complexes}

Optical methods were used to study the various samples synthesized. Infrared spectroscopy is a very useful method for the structure elucidation of compounds, that is ligands and their complexes to show the moiety bonded to the center metals atoms subsequently. IR spectra of ligands and their metal complexes obtained from substances initially taken for synthesis were recorded on a Nicolet IS10 spectrophotometer from Thermo Scientific (USA) in the range of $4000-400 \mathrm{~cm}^{-1}$. The difference between the ligand spectrum and its complexes showed coordination of Schiff base with metals ions [8].

In the IR spectra of HL ligand, the absorption band $\mathrm{CH}=\mathrm{N}$ - belonging to the azomethine group is $1608 \mathrm{~cm}^{-1}$, and the absorption band $\mathrm{C}=\mathrm{O}$ belonging to the carbonyl group in the amide group is $1698 \mathrm{~cm}^{-1}$. Two intensive 3279 and $3179 \mathrm{~cm}^{-1}$ strips belong to the $\mathrm{NH}$ groups. Due to the complex formation in the IR spectra of the $\mathrm{Cu}$ (II) and $\mathrm{Ni}$ (II) complexes, the azomethine bond shifts to $1617 \mathrm{~cm}^{-1}$ for the copper complex and $1606 \mathrm{~cm}^{-1}$ for the nickel complex. Observations of the absorption bands $3589 \mathrm{~cm}^{-1}$ in the copper complex and $3465 \mathrm{~cm}^{-1}$ in the nickel complex show that they also contain a water molecule. It was observed from IR spectra and certain bands were common in the spectra of metal complex and ligand which shows successfully synthesis of complex formation. 


\section{UV-Visible Spectra}

The electronic spectra of the ligand $\mathbf{1}$ and its metal complexes were measured using UV-VIS Evolution $60 \mathrm{~S}$ spectrophotometer in ethanol solutions. Absorption bands of 285 and $296 \mathrm{~nm}$ (doublet) and $340 \mathrm{~nm}$ are observed in the ligand $\mathbf{1}$ in the electron spectra drawn in ethyl alcohol (Fig.1). These bands belong to the $\pi-\pi^{*}$ transitions and to the group of azomethine combined with a benzene ring at $340 \mathrm{~nm}$. During the complex formation some changed in the electronic spectra of the complex has been observed. In case of complex $\mathrm{Co}(\mathrm{II})$, strong absorption bands of 225, 265 and bands with low intensity at 300 and $354 \mathrm{~nm}$ appear in the electronic spectra in the UV region [9]. Similar changing in the ligand absorption bands were observed in the electronic spectra of the copper(II) 2 and nickel(II) 3 complexes with sythesized hydrazone ligand $\mathbf{1}$ (Fig.2).

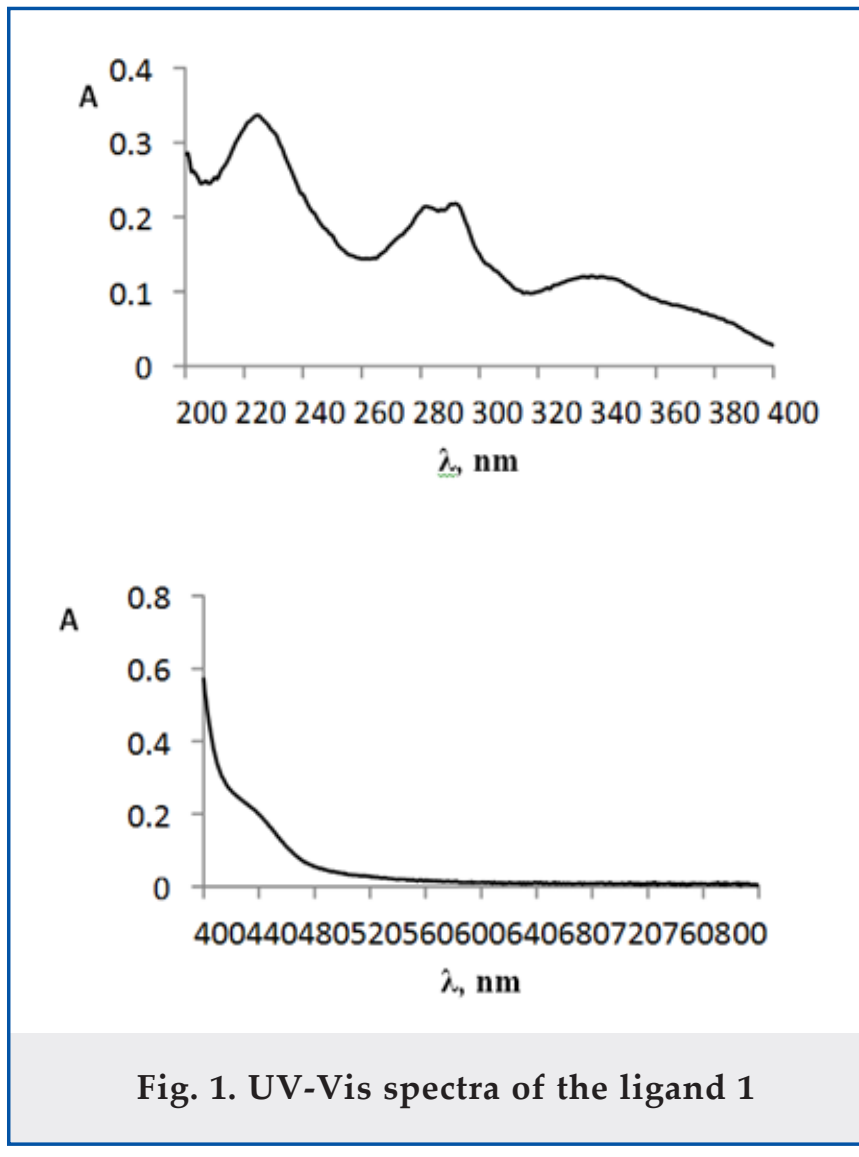

Thus, it was confirmed by spectral methods that malonic acid dihydrazone behaves like a dianion tetradentate ligand and forms plane-square complexes with $\mathrm{Cu}$ (II), Co (II) and $\mathrm{Ni}$ (II) ions. The structure of the obtained complexes can be imagined as follows:

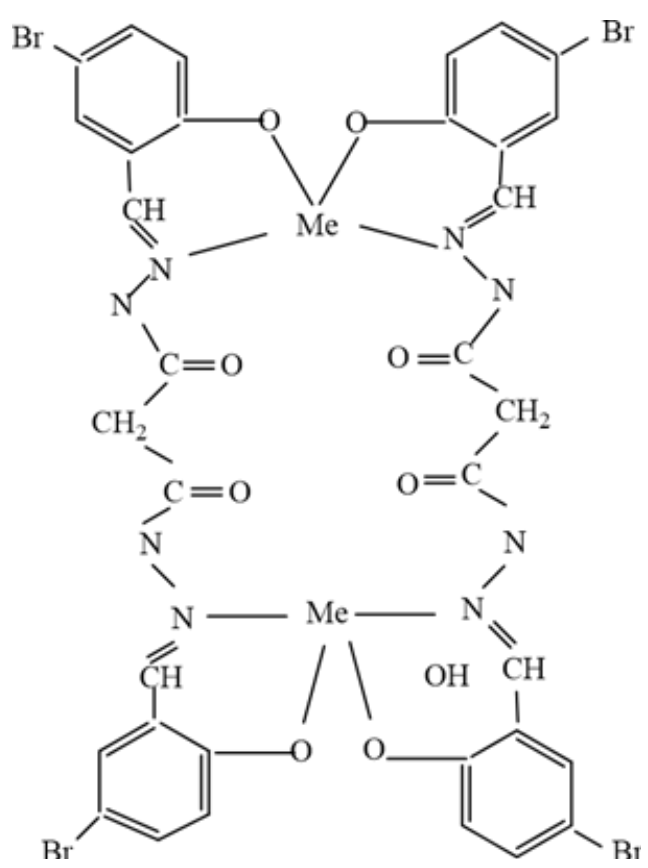

A

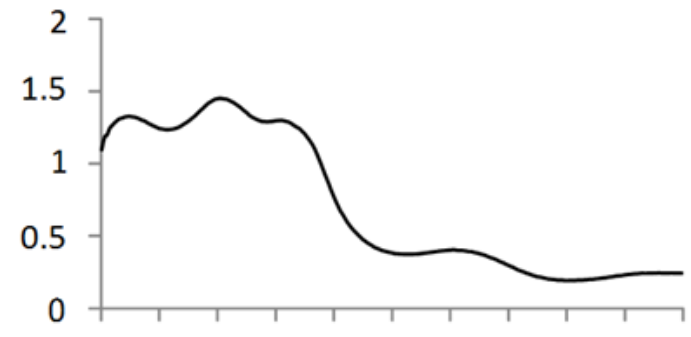

200220240260280300320340360380400

$\lambda, \mathrm{nm}$

Fig. 2. UV-Vis spectra of the Ni(II) complex 3

\section{Conclusions}

Hydrazones of acid hydrazides were synthesized by reacting hydrazides with aldehydes. The esters of malonic acid were reacted with hydrazine hydrochloride to form hydrazides, and then the hydrazide was reacted with 5-bromo salicylaldehyde to synthesize hydrazone. Copper nitrate, nickel nitrate and cobalt nitrate were reacted with as prepared hydrazone to synthesize metal complexes. The hydrazone and metal complexes were characterized by IR and UV-Vis spectroscopy. The IR bands observed around $1617 \mathrm{~cm}^{-1}$ for the copper complex and 1606 $\mathrm{cm}^{-1}$ for the nickel complex, due to $\mathrm{CH}=\mathrm{N}$ - group. The synthesized products showed encouraging results and may be used in different applications. 


\section{References}

1. Mohamad, M. E. Shakdofa, M. H., Shtaiwi, N. M., Tayseer, M. A. A. (2014). Metal complexes of hydrazones and their biological, analytical and catalytic applications: A review. Main Group Chemistry, 13, 187-218.

2. Aly, S. A., Fathalla, S. K. (2020). Preparation, characterization of some transition metal complexes of hydrazone derivatives and their antibacterial and antioxidant activities. Arabian Journal of Chemistry, $13,3735-3750$.

3. Holló, B. B., Magyari, J., Armaković, S., et al. (2016). Coordination compounds of a hydrazone derivative with $\mathrm{Co}(\mathrm{III}), \mathrm{Ni}(\mathrm{II}), \mathrm{Cu}(\mathrm{II})$ and $\mathrm{Zn}(\mathrm{II})$ : synthesis, characterization, reactivity assessment and biological evaluation. New Journal of Chemistry, 40, 5885-5895.

4. Kogan, V. A., Levchenkov, S. I., Popov, L. D., Shcherbakov, I. A. (2009). 1-hydrazinophthalazine based hydrazones and their transition metal complexes: structure and biological activity. Russian Journal of General Chemistry, 79(12), 2767-2775.

5. Svete, J. (2005). Synthesis of functionalized compounds containing pyridazine and related moieties. Journal of Heterocyclic Chemistry, 42, 361-373.

6. Bartos, A., Niedzielski, P., Buczyłko, K., Leszczyńska, J. (2019). Nickel chelate complexes as a target for polyclonal antibodies raised in rabbits and mice. International Journal of Environmental Analytical Chemistry, https://doi.org/10.1080/03067319.2019.1691179.

7. Dzhardimalieva, G. I., Uflyand, I. E. (2018). Design strategies of metal complexes based on chelating polymer ligands and their application in nanomaterials science. Journal of Inorganic and Organometallic Polymers and Materials, 28, 1305-1393.

8. Mandewale, M. C., Thorat, B., Shelke, D., Yamgar, R. (2015). Synthesis and biological evaluation of new hydrazone derivatives of quinoline and their $\mathrm{Cu}(\mathrm{II})$ and $\mathrm{Zn}$ (II) complexes against Mycobacterium tuberculosis. Bioinorganic Chemistry and Applications, 153015, http://dx.doi.org/10.1155/2015/153015

9. Şengül, E. E., Göktürk, T., Topkaya, C. G., Gup, R. (2020). Synthesis, characterization and DNA interaction of $\mathrm{Cu}(\mathrm{II})$ complexes with hydrazone-Schiff base ligands bearing alkyl quaternary ammonium salts. Journal of the Chilean Chemical Society, 65(2). 


\title{
Комплексы металдов с дигидразоном дигидразина мадоновой кисдоты
}

\author{
Р.Х. Исмаилов ${ }^{1}$, П. А. Фатулдаева ${ }^{2}$ \\ ${ }^{1}$ НИПИ "Нефтегаз", SOCAR, Баку, Азербайджан \\ ${ }^{2}$ Институт катализа и неорганческой химии Нацчиональной академии наук \\ Азербайджана, Баку, Азербайджан
}

\section{Реферат}

Представленное исследование включает синтез и характеристику комплексов переходных металлов Cu (II), Со (II) и Ni (II) с лигандом гидразонового основания Шиффа. Аиганд основания Шиффа был синтезирован реакцией эфира малоновой кислоты и 5-бромсалицилальдегида. Строение полученных комплексов изучено методами ИК и электронной спектроскопии.

Ключевые слова: гидразоновый лиганд основания Шиффа; медный комплекс; никелевый комплекс; кобальтовый комплекс; ИК- и УФ-видимая спектроскопия.

\section{Malonik turşusu dihidrazinin dihidrazonu ilə metal komplekslori}

\author{
R.H. İsmayılov ${ }^{1}$, P. A. Fətullaeva ${ }^{2}$ \\ 1"Neftqazelmitadqiqatlayiha İnstitutu", SOCAR, Bakl, Azarbaycan \\ ${ }^{2}$ Kataliz va Qeyri-üzvi Kimya İnstitutu, Azarbaycan Milli Elmlar Akademiyası, Bakı, Azarbaycan

\section{Xülasə} \\ Təqdim olunan tədqiqata Schiff əsaslı hidrazon liqandı ilə Cu (II), Co (II) və Ni (II) \\ keçid metallar komplekslərinin sintezi və xarakteristikası daxildir. Schiff əsaslı liqand, \\ malonik turşusu efiri ilə 5-brom-salisil-aldehidin reaksiyası ilə sintez edilmişdir. Alınan \\ komplekslərin quruluşu İQ və elektron spektroskopiyası vasitəsilə öyrənilmişdir.
}

Açar sözlar: Schiff əsaslı hidrazon liqandı; mis kompleksi; nikel kompleksi; kobalt kompleksi; İQ və ultrabənövşəyi spektroskopiya. 